\title{
Effects of the Foreign Direct Investment on the Productivity of Latin American Countries (1990-2012)*
}

\author{
Efectos de la Inversión Extranjera Directa en la productividad \\ de los países de América Latina (1990-2012)
}

\author{
Ángel Paúl Moreno Plascencia ${ }^{* *}$ y Rafael Salvador Espinosa Ramírez ${ }^{* *}$
}

\begin{abstract}
In a dynamic where international economic integration is constantly growing, multinational enterprises are important to understand the mechanisms that may induce productivity growth. Foreign Direct Investment (FDI) is a response of multinational enterprises to take advantage of a foreign country's economic structure. Using a panel analysis, this study aims to enhance and improve the evidence of the effects of FDI on the productivity of Latin American countries, within an economic approach. The positive relationship between the variables of interest suggests that an increase in FDI inflows would impact the productivity growth of the analysed countries at a fairly high rate. This rate is understandable considering that Latin American economies are characterized by being highly susceptible to radical changes in their respective performances when they have greater access to productive factors; in this case, capital inflows can affect significantly the performance of the countries in this study.
\end{abstract}

Keywords: FDI, Productivity, Latin America.

JEL Classification: C10, C12, F15, F43, F62.

\section{RESUMEN}

En una dinámica donde la integración económica internacional se encuentra en constante crecimiento, las empresas multinacionales son importantes para entender los mecanismos capaces de inducir un aumento en la productividad. La Inversión Extranjera Directa (IED) es una respuesta de las empresas multinacionales para aprovechar la estructura económica de un país extranjero. Mediante un análisis de panel, la investigación intenta aumentar y mejorar la evidencia de los efectos de IED en la productividad de países latinoamericanos, con un enfoque económico. La relación positiva entre las variables de interés sugiere que un incremento de flujos entrantes de IED impactaría positivamente la productividad de los países estudiados a una tasa alta. Los resultados son entendibles cuando se recuerda que las economías latinoamericanas son altamente susceptibles a cambios radicales cuando acceden a mayores factores productivos; en este caso, el flujo de capitales puede afectar significativamente su rendimiento.

Palabras clave: Inversión extranjera directa, productividad, América Latina.

Clasificación JEL: C10, C12, F15, F43, F62.

\footnotetext{
* Fecha de recepción: 16/03/2017. Fecha de aceptación: 27/08/2018.

** Correo: moreno.paul9@gmail.com. ORCID: 0000-0003-4594-2029.

*** Universidad de Guadalajara. Correo: rafaelsa@cucea.udg.mx. ORCID: 0000-0002-5049-9175.
} 


\section{INTRODUCTION}

The economic conditions and institutions play an important role to understand the structure of a country's economy. In the age of international competition, these conditions and institutions are highly related to economic development. Productivity growth is understood as one of the most important factors that may induce a positive change on these conditions and institutions in order to get economic competitive advantage. Productivity growth can be explained as a consequence of international economic integration.

The change in productivity can be understood as one of the most important factors in the nations' economic development. This change in productivity can be explained by international economic integration, assuming that this integration is theoretically unstoppable and constantly increasing. The Foreign Direct Investment represents a huge part of this international economic integration.

In a dynamic environment, where international economic integration is constantly growing, multinational enterprises are important to understand the mechanisms that can induce productivity growth. Foreign Direct Investment (FDI) is, therefore, a response of multinational enterprises to take advantage of a foreign country's economic structure. In order to maximize their benefits, multinational enterprises decide to participate in a foreign market and transfer their productive procedures partially or completely. The interaction between multinational enterprises and local enterprises located in the host country can generate mechanisms that should induce a growth in the host country's productivity. As presented in De la Cruz Gallegos, Boncheva and Ruíz-Porras (2008), Latin American countries are dynamically competing against China to attract FDI from the United States; De la Cruz Gallegos, Boncheva and Ruíz-Porras suggest the existence of a substitution effect for US investment flows between China and a selection of Latin American economies, they demonstrate the real existence of an international competition. This competition should not be understood in a comparative way between China and the Latin American countries, but in a conceptual way, where the economic differences between them are essentially clear. Whatever the economic configuration of the host countries companies still estimate FDI as a profitable practice.

Some of the Latin American economies identify the attraction of FDI as a key factor to increase their competitiveness in the global market, and to increase their economic and social development. Therefore, studying the effects of FDI on the productivity of host countries is needed to understand the real impact of international economic integration in Latin America. This study aims to enhance and improve the evidence of the effects of FDI on the productivity of Latin 
American countries that may be important to identify the political and macroeconomic decisions of the countries in the region.

The present investigation also aims to recognize the interests and motivations that a country identifies in order to attract FDI. Therefore, a deep understanding of topics related to the international economic relations is desired, and the present article hopes to bring conceptual evidence that underlies the role of FDI in a globalized economy. The main objective of this paper is to identify the magnitude of the effects of FDI on the productivity of Latin American countries. They are seeking-investment countries and it is different to the China case, where the productive industry requires a large demand of inputs and investment; however, China maintains different incentives in terms of productivity given primarily by a strong domestic market combined with a vigorous exporting sector. Apart from the peculiar similarities and sharp differences, we focus only on Latin America countries.

Other specific objectives of the investigation are: to identify the kind of interest that stimulates the opening to FDI flows in an economy; to present the definition of productivity and its implications on a nation's economy; to identify the importance of the productivity development in a country's enterprises, within a context of market economy; to determine the productivity's contribution on competitiveness of national economies; to establish the importance of FDI attraction on the economic development of Latin American countries; to specify the role of Latin American national enterprises on the FDI attraction, and to determine if the Latin American countries are able to compete for attracting FDI against other nations and regions around the world.

On the first part of the paper, conceptual aspects regarding productivity and its role in economics are set. This part aims to identify the determinant and influential factors on productivity, and how productivity is measured and defined in current literature. Through the identification of these factors, it is possible to understand the role of productivity on the competitiveness of a country in the international scenario.

The second part of the paper aims to explain the FDI as an economic actor, by reviewing its definition and its different ways of action. Underlying factors and advantages attached to the presence of FDI are also discussed in this part of the paper. We present a global context of FDI flows, and how the attraction of FDI is assessed as a political strategy in order to get economic and social growth. FDI in Latin America is revised in the same part. Economic growth tendencies in Latin America are presented and analysed. Finally, the presence of FDI in Latin America is reviewed, identifying a growing tendency through the recent decades.

The third part consists of a literature review regarding the main subject of the thesis: the influence of FDI on the productivity of host countries. The role of 
productivity is also reviewed, potentiated by the presence of investment flows in regional development. In the same way, the role that multinational enterprises plays in increasing productivity is reviewed, and the investigation attempts to find a relationship between international trade and investment. Finally, we review the role of investment in research and development in order to generate positive changes in the productivity of the countries. All of the above is made in order to form a theoretical framework capable of strengthening the main thesis of the research.

The fourth part presents an econometric model to determine the effects of FDI on the productivity of Latin American countries to generate conclusive and empirical results about this relationship. These results are shown in the fifth part of the present paper.

At the last part, the general conclusions of the research are presented, based on the results obtained in the previous part. Policy implications of the results are presented for the Latin American economies in this study.

\section{PRODUCTIVITY}

In Economics, productivity is understood as the link between production and resources for the same production (labor, raw materials, energy, etc.). Productivity is usually associated with the concept of efficiency: the less time is spent on achieving the desired result, the better the production system will be. Productivity, understood as the level of productive efficiency, is one of the keys to understand the comparative advantages of countries in an international context governed by competition. A highly productive country is better prepared to compete internationally due to its labor and/or technological performances. Therefore, local enterprises have the possibility to participate or increase their participation in foreign markets.

Through the study of productivity, the ability of a productive structure is measured. This productive structure should be efficient enough to develop the demanded products according to the available resources in an economy. Increasing productivity often means a better profitability for every enterprise. When the enterprises differ in their performance, economic integration generates winners and losers. The most efficient enterprises -the ones with lowest production costs - thrive and tend to grow; meanwhile, the least efficient enterprises - the ones with higher production costs - tend to shrink and could be forced to leave the market (Krugman, Obstfeld \& Melitz, 2012).

Productivity can be induced to change by certain factors of the productive activity. These factors could be both internal and external to the productive activity, 
and they are often are linked to the access of resources. This kind of factors could be the constant access to good resources, the opportunity to get better resources or enhancing the use of the same ones, the advantages associated to the presence of FDI flows, the ability to improve the productive process by having access to scientific and technological development, and other external factors regarding the social life and stability of the society where the productive activity is held.

The Total Factor Productivity (TFP) is a way to measure the productivity of an economic structure. It takes into consideration the efficient use of many resources of an economy, and by definition, TFP is a representation of the variation in the performance and the use of any of the production factors (López-Pueyo, Barcenilla, Mancebón \& Sanaú, 2008). There is more than one way to measure the TFP, and in here, it is measured by the calculation of the elasticities of the production factors for each economy, as it will be seen later on.

The industry is defined as the engine of economic growth. According to the laws of Kaldor, the rapid growth of manufacturing output directly affects the increase in labor productivity by increasing returns to scale. Thus, productivity is endogenous to economic activity, which, in turn, results in a greater demand for products that directly affect competitiveness and increase productivity. Recent studies seem to confirm this theory by showing that national economies, such as Mexico, have been unable to complete a process of industrialization, generating structural difficulties and imposing limits to growth. Productivity, stuck in a system that does not allow growth rate in manufacturing, is hampered by the inability of industrialization (Calderón Villarreal \& Sánchez Juárez, 2011).

For a nation state, promoting productivity can be seen as an action to promote economic development and social welfare. In some countries, there is even the figure of special laws that attempt to boost development in productivity. Generally, these laws are strongly related to the industrial development policies of nations. The industrial development, which can be defined as the set of public policies aimed at creating and attracting production companies, is a strategy that most Latin American governments have adopted at least once in the past century with the aim of encouraging industrial development (Witker, 2010).

The process of economic globalization brings about a scenario where the innovation of production processes is emerging as the main factor in the search for competitiveness. Industrial development has, therefore, other considerations, such as education, promoting scientific research and technological development, and all kinds of issues that may directly or indirectly impact the performance of production systems.

Technology transfer is a key to the process of economic growth, both between developed and underdeveloped countries, and has a high impact on productivity. Linked to the idea of the product cycle, technology transfer generally occurs after 
a series of inventions and innovations, often via trade, particularly between the innovative firm and its affiliates or licensees. Technology transfer is an economic term meaning the exchange, of technology, made among countries. This buying and selling of technology among nations include patents, patent licensing, trademark licensing and compound, support, and application of scientific and technological knowledge, among others.

\section{ENDOGENOUS GROWTH MODELS AND PRODUCTIVITY}

Productivity is highly related to growth. Certainly, the theory of endogenous growth implies the existence of investment related mainly with human capital. One of the origins of human capital in Latin American countries comes from the Foreign Direct Investment. In this sense, we should review the literature on endogenous growth models in order to understand properly the place of Foreign Direct Investment in productivity and growth.

There are two branches of analysis in economic growth: the neoclassical, based on Solow's growth model, has emphasized the importance of investment. The recent literature shows the theory of endogenous growth developed by Romer and Lucas, who have drawn attention to human capital and innovation capacity. Both are part of the definition of productivity in this paper. Apart of this two, a special contribution to growth theory is the New Economic Geography School (NEG).

The endogenous growth theories remark the role of technological progress as a key driver of long-run economic growth, which accepts constant and increasing returns to capital. These theories propose that the introduction of new accumulation factors, such as knowledge and innovation, induce self-maintained economic growth. The seminal papers were published by Romer (1986) and Lucas (1988); they start the endogenous growth theories regarding three sources of growth: new knowledge (Romer, 1990; Grossman \& Helpman, 1991), innovation (Aghion \& Howitt, 1992) and public infrastructure (Barro, 1990). Specifically we focused on the literature that emphasized the importance of education on growth (Barro, 1991; Mankiw et al., 1992; Sala-i-Martin et al., 2004; Barro \& Sala-i-Martin, 1995) where education is a key measurement tool and proxy for the quality of human capital in the sense that educated and skilled workers, with a higher productivity, can have an important contribution to growth.

On the other hand, the NEG asserts that economic growth tends to be an unbalanced process favoring the initial advanced economies (Krugman, 1991; Fujita et al., 1999). In here, there is a systematic explanation about increasing returns to scale, imperfect competition and non-zero transportation costs. Economic activity 
tends to agglomerate in a specific region and choose a location with a large local demand resulting in a self-reinforcing process. NEG is mainly concerned with the location of economic activity, agglomeration, and specialization rather than economic growth. However, growth comes with agglomeration.

Investment is the fundamental determinant of economic growth in the endogenous growth model in the long-run. There is enough empirical evidence between investment and growth, and particularly the investment in having skilled workers as in Barro and Sala-i-Martin (1995) and Sala-i-Martin (1997). Human capital is the main source of growth in several endogenous growth models. Evidence suggests the strong relationship between education and economic growth as in Barro (1991), Mankiw et al. (1992), and Barro and Sala-i-Martin (1995). Specifically, innovation and Research and Development can play a major role in economic progress increasing productivity and growth.

Openness to trade has been used in economic growth literature as an important determinant of growth performance by the use of comparative advantage, technology transfer and diffusion of knowledge, increasing scale economies and exposure to competition. Particularly, Foreign Direct Investment has played a crucial role in internationalizing economic activity and it is the primary source of technology transfer and economic growth. This role is remarked in several models of endogenous growth theory. There exists a significant positive link between Foreign Investment and growth as in Borensztein et al. (1998), Hermes and Lensink (2000), Lensink and Morrissey (2006), and Azeroual (2016).

The soul of the endogenous growth model comes from the impact of human capital on growth where productivity is the core of the discussion. In Latin American countries it is considered that this investment in human capital arises from external sources as Foreign Direct Investment. There is evidence for this argument.

\section{FOREIGN DIRECT INVESTMENT}

Foreign Direct Investment is often considered as a response by the enterprises in order to take advantage of other country's institutional and economic conditions. Every Multinational Enterprise (MNEs) wants to maximize the profitability, in some cases through increasing the productive performances. When the exportation costs are relatively high, enterprises are encouraged to locate their production nearer their clients in order to be competitive. Therefore, the FDI is a response to the need of reducing the production and exportation costs and brings the opportunity of increasing the participation in a specified market (Krugman et al., 2012). 
The difference between the countries' factors relies on their existence, which is the key to understand FDI. FDI can be defined as capital movements which are met by a country, commonly referred to as the recipient country. The enterprises who decided to use the FDI expect control over factors. Capital flows, following the logic of the theory of comparative advantage of David Ricardo, are able to motivate potential benefits for both the countries of origin of the investment and recipients. These advantages are associated with the efficiency of using factors that can be used more intensively according to each economy and the resources at its disposal (Juárez Rivera \& Ángeles Castro, 2011).

International trade, therefore, is fundamental to understand the motivation behind FDI. Widespread openness allows the creation of an integrated market that is much bigger than any domestic market. This integrated market can, if handled with clarity and a good rule of law, simultaneously offer consumers a variety of products at low prices and encourage competitiveness between companies. The FDI is displayed as the logical response to reap the benefits that an integrated market offers. Recently, more benefits of international trade have been included on the theoretical framework. These benefits include facilitation on learning, specialization of labor, economies of scale, capital accumulation, incoming foreign investment, and better import capacity (Fujii, 2011).

Supposedly, according to a number of economic assumptions, FDI fosters the development of the territory and the society in which it is located. FDI flows may positively affect the development of recipient nations directly through the formation of human capital, technology transfer and innovation in production processes, which make the recipient nation a more efficient, with better competitive performance and marginal income for workers. Indirectly, multinational companies can influence the development of road, port and airport infrastructures of host nations, improving efficiently the way of communication that benefits all parties. The very presence of a multinational company that has decided to relocate its production in a foreign country, gives the opportunity to the same country to generate wealth that can be equitably distributed (Díaz González, 2011).

The company that ventures into a foreign market must, by definition, have a check on its competitive advantages in whatever it is producing. Therefore, its presence in a host country can improve productivity, whether reducing administrative costs or increasing the productive performance of labor and capital (Juárez Rivera \& Ángeles Castro, 2011). If a foreign enterprise is in a position of need to invest in other countries to maximize its benefits, this enterprise is able to innovate in terms of the quality of existing products, production processes, and organizational structures. All these advantages linked to the innovation are absorbed, one way or another, by the host country (Neme Castillo \& Valderrama, 2011). 
The presence of foreign companies encouraged the relocation of resources and possibilities of production of goods and services more efficiently. This allows the recipient countries exploit in a better way their comparative advantages in a context of international competition (Juárez Rivera \& Ángeles Castro, 2011).

Foreign companies that venture into alien countries are able to capture new foreign markets, both for themselves and for other companies of the recipient country with which they relate. The internationalization of these national companies, then, seems more feasible. The competitiveness of the recipient nation improves through cost reduction, which occurs as a result of the presence of foreign companies that raise processes due to changes in demand and supply conditions (Juárez Rivera \& Ángeles Castro, 2011).

Over the years, the movement of capital between countries has been one of the primary tools for understanding economic interdependence. Since the financial movements have been recurrent, economic interdependence has been symbolized by the exchange of capital between countries. Foreign investment, then, substantiates the exchange of capital between nations and becomes an essential tool for understanding economic interdependence.

Foreign investment, especially FDI, has experienced relevant growth over the last four decades. It is understood in principle that foreign capital flows should present a balance; inflows worldwide should equal the outflows. It is needed to understand that international capital flows usually depend on the economic performance of the countries of origin, so it is not surprising that FDI is dramatically reduced when national economies suffer for a period of time. Despite this, FDI flows have experienced a growth to quadruple during the decades of the 1990s and 2000s (Krugman et al., 2012).

However, economies, that have experienced high growth in recent years, have also increased international capital outflows. Countries like China itself, India and Russia are today within the first twenty-five countries with the most FDI in the world. On the other hand, no country in Latin America is contained within the first thirty countries, although it is understood that the region is much more FDI recipient that issuer.

The promotion of economic returns and institutional facilities is recurrent in the economic policies of the countries. As mentioned earlier, foreign companies prefer to invest in another country if it offers them the conditions for labor instead of trading from their country of origin as long as it is more profitable for their purposes. Countries that are generally recipients of FDI can enjoy a reputation based on the experience that other countries can hardly get in a short period of time. The same international agreements related to the protection and copyright, for example, offer advantages to those countries that have signed such agreements overs those who choose not to. In the same 
way, the signing of bilateral agreements on international trade or strategic alliances in economic matters often responds to the search for the reputation of the countries, to maintain, create or increase agreements with other countries, with which, perhaps, there is a greater interest.

FDI in Latin America was also potentially increased during the middle and late 1990s, following a trend of global scale. Historically, the United States (US) has been the source of most foreign investments in Latin American territory, positioning the European Union (EU) as the second largest investor in the region. According to the United Nations Economic Commission for Latin America and the Caribbean (ECLAC; CEPAL, in spanish), the Latin American and Caribbean region receives twelve percent of FDI inflows made worldwide. Economic growth in the region, which has maintained a positive trend despite major complications that the international economy has experienced in recent times, has helped to sustain the level of foreign investment in the region. With annual increases of FDI close to six percent, Latin America presents itself as an important destination for global investment and offers potential benefits to investors even when uncertainty has dominated international economic relations in recent years (CEPAL, 2014).

In Latin America, attracting FDI diverges between countries, despite maintaining a positive and consistent trend. According to ECLAC (CEPAL, 2014), increases in the most significant FDI flows in the region were observed in countries like Peru (increases of up to 49 percent), Chile (32 percent), Colombia (18 percent) and Argentina (27 percent). However, the role of Brazil as the largest recipient of foreign investment cannot be subject to discussion, agglomerating 38 percent of the total investment made in the region. On the other hand, Mexico has suffered a decline of FDI inflows, which places the country at levels that appeared at the end of the decade of the 1990s. Chile, meanwhile, becomes the second economy in attracting FDI in the region.

Transnational corporations have consolidated their presence in Latin America, mainly in capital-intensive sectors that generate high-income flows (CEPAL, 2014). If we start from the idea that global FDI flows must be in balance (FDI inflows worldwide coincide with FDI outflows), then is acceptable to think that Latin America competes with other geographical regions to attract flows of investment from both developed and developing countries, which is consistent with De la Cruz Gallegos, Boncheva and Ruíz-Porras (2008). The expansive economic cycle on most Latin American countries and the price of raw materials exports in the region suggest that FDI flows remain on a positive and growing trend since both are factors favoring the rates of return on investments.

The change in productivity can be understood as one of the most important factors in the nations' economic development. This change in productivity 
can be explained from international economic integration, assuming that this integration is unstoppable and constantly increasing. The Foreign Direct Investment represents a huge part of this international economic integration.

Some of the Latin American countries identify the attraction of Foreign Direct Investment as one of their principal objectives in search of economic development. The interaction between the Latin American economies and other economies in the world is, therefore, relevant to understand the impact of national policy-making on international economic relations. In other words, studying the effects of the Foreign Direct Investment on the productivity of Latin American countries is relevant in order to encourage the debate on economic policies in the region, in a global instance, where political and institutional changes are taking place at the US and EU, principal partners of most of the Latin-American countries.

Even when the main reason why multinational companies decide to expand is profit, there are many other reasons behind the motivation of multinational companies to adopt FDI. Firstly, MNEs seek access to cheaper resources, raw material, and labor. Secondly, MNEs may have market-seeking motives in order to increase their sales and obtain higher profit. Thirdly, MNEs might want to expand their operations because of efficiency-seeking motives. All of these reasons do not guarantee a better labor productivity in the host FDI country because they are not necessarily interested in productivity at all.

The seeking-access for cheaper resources, raw materials and labor seem to be the primigenial reasons for foreign investors. MNEs increase workplaces; thereby they reduce the unemployment rate in the host country, although more employment does not mean more productivity. However, with greater access to resources and raw materials, there may be some environmental degradation as legal restrictions are weak. While host countries can benefit from the positive effects of investment, the negative effects of FDI on the host country's ecosystems and environment might bring disaster in the long run (Gray, 2002).

Local firms might increase their productivity as a result of gaining access to modern, improved, or cheaper intermediate inputs and technology produced by MNE in upstream sectors; it is called spillovers effect (Javorcik, 2004). In the same sense, the presence of MNEs assists the economic development by stimulating the domestic competition leading to higher productivity, innovation and more efficient resource allocation (OECD, 2002). However, FDI can have both crowdings in and crowding out effects in the host country economy. The main negative effect of crowding out effect is the monopoly power over the market gained by MNEs (Agosin \& Mayer, 2000; Kumar \& Pradhan, 2002). This monopolistic impact is even contrary to the productivity argument. 
Wage spillovers of the FDI are considered to be positive as workers of MNEs can leave their workplace and become entrepreneurs in the future, which increase the productivity of domestic firms. However, it might cause negative consequences as well, especially, if MNEs hire the best workers due to their high wages and thereby leave lower-quality workers at the domestic firms affecting negatively the productivity (Lipsey \& Sjoholm, 2004).

In general, FDI may prove to be beneficial or harmful to host countries. One of the possible benefits is increasing productivity but it is not clear at all. Even when the literature may be contradictory on the effect of FDI on productivity, we will consider the positive relationship between FDI and productivity.

\section{THE ROLE OF FDI ON PRODUCTIVITY GROWTH}

Defining the role of FDI on productivity has been a matter of interest for the academic world during the last decades. Assuming that private investment and foreign investment on host nations' industries can affect significantly the productivity growth, the specialized literature has tried to quantify the effects of FDI on TFP on a global level. For instance, Fons-Rosen, Kalemli-Ozcan, Sorensen, Villegas-Sanchez, and Volosovych (2013) have not found empirical evidence on the growth of FDI and its incidence on TFP performance. FDI impacts TFP on a global scale, but not on a significant level. Even so, the effects of FDI on TFP could explain proportionally the performance of productivity on continental and/or country scales.

On a country-scale level, Ramírez (2005) has tried to quantify the impact of FDI on labor productivity in Chile. Ramírez suggests a positive incidence between FDI inflows and labor productivity by measuring these effects on a cointegration analysis and an error-correction model. It is understood that FDI inflows have had a positive relationship with Chile's labor productivity in the 1960-2001 interval of time. Ramírez concludes that recent economic turbulence, like the financial crisis in the last decade, can be fixed in subsequent times and should not necessarily involve a long-term decline on labor productivity.

Campos Pereira, Leal Calegario and Pereira Reis (2013) found a causal effect on productivity and FDI inflows for the case of Brazil. By using a Generalized Linear Model, estimated on the basis of the theoretical common determinate factors for FDI, a series of linear equations were defined. This work suggests not only a positive relation between FDI and productivity but a causal effect of productivity -on a cross-industry approach- on the attraction of higher FDI inflows. According to their conclusions, an individual analysis of Brazilian industries has a relevant role in the decision of foreign firms to invest in the country. Apparently, low-productive industries represent potential opportunities for foreign firms. 
According to Wang (2010), the links between industries could explain the FDI effects on the productivity of Canada. These links could be associated with productive chains and logistics practices. Wang tries to prove that the presence of FDI - and foreign firms in a host economy- affects positively the TFP by improving the same productive chains and logistics practices when local firms have contact with newer capacities, associated to the presence of foreign producers. When a foreign firm enters into a host economy, the firm interacts with the local ones generating - directly or not, technical spillovers-. By adopting a multiple linear regression analysis, Wang established that the performance of local firms in Canada is significantly better, mainly on highly linked industries that received FDI.

Another factor that could induce an improvement in product performance is technology transfer. Van Pottelsberghe and Linchtenberg (2000) try to prove that a host FDI country can benefit from the Research and Development (R\&D) made by other countries around the globe. According to their study, this benefit can be understood as an indirect effect of international trade and capital flows between both countries - the sender and the recipient of FDI-. It establishes that the TFP is a function of the intellectual capital of a country and the flows of investment from abroad, especially in the form of FDI.

Van Pottelsberghe and Linchtenberg (2000) conclude that the productivity of a country grows only if its national firms invest in foreign economies with a high level of R\&D, and not vice versa. Also, they found that the advantages of having technological transfer through FDI inflows are highly better in main economies than the small ones.

For Takki (2001), there is a positive change in productivity due to the presence of foreign firms in a host country. By adapting a regression model analysis to the Indonesia case, Takki has found that this positive change in productivity is only significant if the hosting industry does not have a technological lag. Takki concludes that the magnitude of the productivity changes depends entirely on the characteristics of local firms in the country and foreign firms that are already located there.

It is also relevant to explain the role of Outsourcing practices on the host economies performances. Outsourcing is a common mechanism of multinational enterprises with a presence on foreign economies. When the enterprises use external resources from other firms, they create links in order to guarantee the fulfillment of specific tasks, explaining the relation and incidence between the performance of foreign firms and the productivity of local enterprises. Görg, Hanley, and Strobl (2005) use a panel data analysis to determine the incidence of Outsourcing in the productivity of firms that practice it. Their results suggest the existence of positive effects of Outsourcing on the productivity of local or 
existing firms in the economy, but only if these local firms are affiliated to or owned by other multinational firms.

Technological and industrial competitions are constant in a globalized economy. Technological leadership represents a highly competitive advantage between the most powerful economies in the world. According to Luintel and Khan (2004), there is a political and economic competition between the G7 countries around the control for technological leadership. Estimating the TFP on the function of $R \& D$, the authors adopted a vector correction model able to measure the heterogeneity level of the impact of R\&D on productivity. As expected, Luintel and Khan proved there is no heterogeneity in the impact of R\&D on the productivity of G7 countries, but these effects are highly significant in most cases, even when the knowledge distribution is not uniform. Other estimations with equivalent results in the matter of technology transfer and the R\&D relevance on productivity change have been made by Coe and Helpman (1995), Keller (1997) and Stehrer and Woerz (2009), among others.

However, productivity growth takes into account the receiving sector of FDI. Empirically FDI in Latin America goes to the manufacture sector rather than other sectors. According to ECLAC in their 2018 report on FDI in Latin America and the Caribbean, from 2011 to 2017 the only economic sector with increasing FDI is the manufacture one; there was a declining flow of FDI in the rest of the economic sectors in the entire region. According to ECLAC, in the last 20 years, the flow of FDI into Latin American manufacture sector is given by efficiency reasons. In such a scenario, the firms are looking for efficiency in the adequate use of technological resources (CEPAL, 2018). This efficiency impacts positively in general in the competitiveness and productivity of the TFP in the region. However, there are contrasting results at the country level since other factors impact the TFP in each country. While productivity has grown consistently in Mexico in the last 20 years, some ambiguous results have been observed in Argentina, Brazil, and Colombia in the same period (CEPAL, 2018).

For instance, (Jordaan, 2008) argues that the flow of FDI in Mexico goes mainly to the manufacturing industry. FDI is significantly aimed at the automotive industry in Mexico, Argentina, and Brazil, and it is quite relevant for the increase in productivity. However, there are social and political conditions that impact ambiguously on these countries.

For the Mexican case, Mendoza (2011) measures the impact of FDI on the manufacturing sector from 1999 to 2008, which is positive. Alfaro and Rodriguez-Clare (2004) discover the existence of several potential advantages from domestic firms in the presence of FDI. Since the last 25 years, the role of research and development has grown with FDI into developing countries in general and 
Latin America countries in particular, a proper technological development is the starting point for the spillover effects (Kokko, 1994). Implicitly we are focusing on the FDI coming into the manufacturing sector in this paper. This is relevant in terms of our final conclusions as for the conjectures and possible explanations supporting this paper are shaped by the sector approach.

FDI and the mechanisms it involves are able to induce a productivity change in host countries. Among other international economic mechanisms, as trade and international outsourcing, FDI finds its way to improve -in most of the cases - the productive performance of host countries and their industries. In the case of Latin America, the impact of FDI on the productivity of the economies in the region, in a continental and cross-country level, has not been analysed. Even when the exploitation of FDI in local economies depends on local structures -economically, politically and institutionally-, most of the countries in Latin America have been coherent to global standards and tendencies, and FDI attraction could be understood as a highly desired strategy to improve the productivity level and the economic competitiveness of countries in the region. This study aims to quantify the effects of FDI on TFP for Latin American countries in the past two decades.

\section{METHODOLOGY}

Due to the character of the proposed research, which tries to determine the effects of an economic factor on another, it is understandable that this is a quantitative investigation. A regression analysis has been adopted as a statistical tool to link the economic theory with valid and empirical results. The following methodology is an application of an econometric model, as shown in Tayebi and Ghanbari (2008) for the countries of the Association of the Southeast Nations (ASEAN).

The sources of economic growth have been analysed with special interest since the emergence of endogenous growth theory in the early 1980s. Some authors consider that the major engine of growth in productivity and technological development is innovation (Coe \& Helpman, 1995). The productivity of a country depends mostly of its efforts on improving technological innovation and Research and Development (R\&D) as well as the efforts of its partners in the same areas. The model of Coe and Helpman (1995) focuses on the growth of Total Factor Productivity (TFP). According to Kao, Chiang and Chen (1999), the increase in production is determined by the TFP; and Coe and Helpman model attempts to measure TFP as: 


$$
\log T F P=\log Y-\theta \log K-(1-\theta) \log L
$$

Where $y$ is the final production, $L$ is the available labor force, $K$ is capital accumulation, and $\theta$ is the capital contribution to Gross Domestic Product (GDP).

It is possible to establish a link between TFP and capital accumulation on domestic R\&D. Investment in R\&D of a country can either expand the number of inputs available or improve the quality of these inputs (Kao et al., 1999). Thus, the production function of a simple closed economy is assumed to be a linearly homogeneous function in the inputs used. In addition, if the economy opens to the outside through international trade, the country can take advantage of access to new inputs from the rest of the world. Therefore, efforts in innovation and R\&D of the business partners of a country become relevant for understanding the changes in TFP in the same country. According to Coe and Helpman (1995), and Kao et al. (1999), the PTF can be improved by trade liberalization, and would be measured as:

$$
\log T F P_{i}=\alpha_{\theta i}+\alpha_{d} \log S_{d i}+\alpha_{f} \log S_{f i}
$$

Where $i$ is the country index, $S_{d i}$ represents the domestic R\&D capital stock, and $S_{f i}$ represents the foreign R\&D capital stocks defined as the import-share-weighted average of the domestic R\&D capital stocks of trade partners. In this regard, Kao et al. (1999) assume that if two countries with the same composition of imports face the same conditions of R\&D capital stocks of its trading partners, the country that imports relatively more to GDP can receive more benefits from foreign R\&D. Under this assumption, equation (2), which measures the interaction between R\&D and foreign trade level, changes to:

$$
\log T F P_{i}=\alpha_{\theta i}+\alpha_{d} \log S_{d i}+\alpha_{f}\left(m_{i} \log S_{f i}\right),
$$

Where $m_{i}$ stands for the fraction of imports relative to GDP for country $i$. According to Tayebi and Ghanbari (2008), the equation means that domestic and foreign R\&D capital stocks are components of capital patterns which influence total productivity in the country.

International outsourcing has become one of the most significant effects of trade liberalization. It is understood as a way for firms to look for cheaper suppliers and cope with increasing international competition. Outsourcing firms sometimes purchase a key intermediate input from more efficient suppliers that are also their rivals in the final goods market. Feenstra and Hanson (1997) develop an empirical framework to assess the importance of trade and technical change on the wages of production and non-production workers. They find that 
both international outsourcing and R\&D expenditures can explain a substantial amount of the increase in wages of high-skilled workers relative to low-skilled workers. In their paper, Feenstra and Hanson show how international outsourcing and purchases on high-tech capital affect TFP.

Therefore, the variable $m_{i} \log S_{f i}$ in equation (3) which stands for the interaction between the foreign R\&D capital stocks and the level of international trade, can be approximated by variables of international outsourcing and FDI spillovers. Thus, it is considered that the domestic R\&D capital stocks $\left(S_{d i t}\right)$, international outsourcing $\left(O S_{i t}\right)$ and FDI spillovers $\left(F D I S_{i t}\right)$ are the effective determinants of the total productivity of a country and they are expected to affect positively the TFP. Equation (3) becomes:

$$
\operatorname{lnTFP} P_{i t}=\alpha_{d} \log S_{d i t}+\alpha_{o s} O S_{i t}+\alpha_{F D I} \ln F D I S_{i t}+U_{i t}
$$

Where $O S_{i t}$ stands for international outsourcing of country $i$ in time $t$. This variable is measured by the ratio of imported intermediate inputs with respect to non-energy intermediates (replaced by non-oil GDP due to the lack of data) in the country. $F D I S_{i t}$ denotes FDI spillovers. At the end, $U_{i t}$ stands for disturbance terms in the equation.

We applied panel data to estimate the TFP for each country. The use of panel data is well known in the empirical literature and its use in this paper allows us to confront a robust relationship between FDI and productivity. The use of this econometric instrument provides information about time and space that, even though it may be relatively expensive and not always viable, permits a deep analysis of the relation between FDI and productivity, controlling for non-observable, inherent factors for the countries and the region where they come/ go from/to. The present investigation uses data from seventeen Latin American countries over 1990-2012. TFP data is measured for each country according to the estimation of a Cobb-Douglas production function (López-Bazo, Serrano \& García-Sanchis, 2003). This function is defined as:

$$
Y_{i t}=A_{i t} \cdot K_{i t}^{\alpha} \cdot L_{i t}^{\beta}
$$

Where $Y$ stands for national GDP, $k$ stands for capital stocks, $L$ denotes labor and $A$ denotes the productivity level. The equation is transformed as:

$$
A_{i t}=T F P=\frac{Y_{i t}}{K_{i t}^{\alpha} \cdot L_{i t}^{\beta}}
$$


To estimate TFP for country $i$ in time $t$, it is needed to apply a logarithm form, which is specified as follows:

$$
\ln P T F=\ln Y_{i t}-\alpha \ln K_{i t}-\beta \ln L_{i t}
$$

Where $\alpha$ is capital elasticity and $\beta$ is labor elasticity.

The data has been obtained from the World Bank, with specific contributions from International Monetary Fund, and central Banks and official statistical institutes from each country.

The countries studied in this investigation are the following:
Argentina (ARG).
El Salvador (SLV).
Bolivia (BOL).
Guatemala (GUA).
Brazil (BRA). Honduras (HON).
Chile (CHI). Mexico (MEX).
Colombia (COL). Nicaragua (NIC).
Costa Rica (CRC).
Panama (PAN).
Ecuador (ECU).
Peru (PER).
Dominican Republic (DOM).
Venezuela (VEN).
Uruguay (URU).

No problem related to the sample of data was found. There is a correlation, different from zero, between the variables, and the disturbance terms behave in a normal way.

\section{DATA ANALYSIS}

A panel data has been structured according to the number of observations of the data sample. In total, the model is composed by 391 observations for seventeen countries of the Latin-American region. According to the function (iv), the data has been transformed into logarithm terms. The use of dummy variables was also included in order to label each observation to its corresponding country, and on a year-to-year basis. The results have been obtained using Stata 12.0. In order to obtain the capital elasticity $a$ and the labor elasticity $\beta$, the following function has been applied for the data sample of each country:

$$
\ln T F P=\ln Y_{i t}-\alpha \ln K_{i t}-\beta \ln L_{i t}
$$


Statistical tests report no problems with the sample of data. Once the $\ln P T F$ has been calculated for each country, it is possible to calculate the effects of FDI in the productivity of Latin American countries by the application of the following function, both individually and jointly:

$$
\ln T F P_{i t}=\alpha_{d} \log S_{d i t}+\alpha_{O S} O S_{i t}+\alpha_{F D I} \ln F D I S_{i t}+U_{i t}
$$

Due to the lack of data, it was impossible to include the variable $\left(S_{d i t}\right)$ that stands for the domestic R\&D capital stocks. It is expected that the FDI has a positive effect on TFP. Results of the model are shown in the following tables.

Table 1. Results of the model for the seventeen economies.

\begin{tabular}{llllrrr}
\hline & OS & InFDIS & Constant & Number of Obs. & F-Statistics & $\mathbf{R}^{2}$ \\
\hline \multirow{2}{*}{ InTFP } & -5.523963 & 1.398218 & -18.66405 & 391 & $7.72^{* * *}$ & \multirow{2}{*}{0.0382} \\
\hline
\end{tabular}

Table 1: Results obtained by the application of function (4) for the seventeen economies (jointly) in study. The bias-corrected t-statistics are reported in parentheses. ${ }^{*}$ denotes significance at the 10 percent. ${ }^{* *}$ denotes significance at the 5 percent. *** denotes significance at the 1 percent. The results have been obtained using Stata 12.0.

In Table 1, the estimator gives us a significant elasticity of TFP and FDIS. The effect of FDI spillovers on TFP is positive and significant for all the countries in a jointly way. The coefficient estimated reveals a strong relationship between FDIS and productivity growth in the countries of Latin America. Hence, in addition to international outsourcing, domestic firms can benefit from direct contact with foreign firms. 
Table 2. Results of the model per country.

\begin{tabular}{|c|c|c|c|c|c|c|c|}
\hline & Country & os & InfDIS & Constant & $\begin{array}{l}\text { Number } \\
\text { of Obs. }\end{array}$ & F-statistics & $\mathbf{R}^{2}$ \\
\hline \multirow{17}{*}{ InTFP } & ARG & $\begin{array}{r}0.4989 \\
(2.67)^{* * *}\end{array}$ & $\begin{array}{l}0.0514 \\
(1.66)^{*}\end{array}$ & $\begin{array}{r}13.5481 \\
(15.76)^{* * *}\end{array}$ & 23 & $3.59 * *$ & 0.2642 \\
\hline & $\mathrm{BOL}$ & $\begin{array}{r}0.5019 \\
(3.06)^{* * *}\end{array}$ & $\begin{array}{r}0.0031 \\
-0.82\end{array}$ & $\begin{array}{r}-5.2631 \\
(-20.37)^{* * *}\end{array}$ & 23 & $4.70 * *$ & 0.3196 \\
\hline & BRA & $\begin{array}{r}-0.2272 \\
(-2.06)^{* *}\end{array}$ & $\begin{array}{r}-0.0066 \\
(-0.51)\end{array}$ & $\begin{array}{r}-5.0881 \\
(-11.55)^{* * *}\end{array}$ & 23 & $2.70^{*}$ & 0.2128 \\
\hline & $\mathrm{CHI}$ & $\begin{array}{r}0.0317 \\
-0.23\end{array}$ & $\begin{array}{r}0.0064 \\
-0.49\end{array}$ & $\begin{array}{r}-15.4017 \\
(-53.86)^{* * *}\end{array}$ & 23 & 0.22 & 0.0214 \\
\hline & $\mathrm{COL}$ & $\begin{array}{r}0.0759 \\
-0.48\end{array}$ & $\begin{array}{r}0.0051 \\
-0.32\end{array}$ & $\begin{array}{r}-3.2801 \\
(-8.78)^{* * *}\end{array}$ & 23 & 0.21 & 0.0204 \\
\hline & CRC & $\begin{array}{r}0.0261 \\
-0.1\end{array}$ & $\begin{array}{r}0.0099 \\
-0.29\end{array}$ & $\begin{array}{r}-3.1449 \\
(-3.35)^{* * *}\end{array}$ & 23 & 0.05 & 0.0049 \\
\hline & DOM & $\begin{array}{r}0.3181 \\
(2.65)^{* * *}\end{array}$ & $\begin{array}{r}-0.024 \\
(-1.61)^{*}\end{array}$ & $\begin{array}{r}-18.2721 \\
(-63.76)^{* * *}\end{array}$ & 23 & $3.75^{* *}$ & 0.0415 \\
\hline & $\mathrm{ECU}$ & $\begin{array}{r}-0.0701 \\
(-0.90)\end{array}$ & $\begin{array}{l}0.0041 \\
(1.37)^{*}\end{array}$ & $\begin{array}{r}1.0233 \\
(7.87)^{* * *}\end{array}$ & 23 & 1.5 & 0.1305 \\
\hline & SLV & $\begin{array}{r}0.8704 \\
(2.80)^{* * *}\end{array}$ & $\begin{array}{r}-0.0042 \\
(-1.27)\end{array}$ & $\begin{array}{r}-21.4229 \\
(-54.96)^{* * *}\end{array}$ & 23 & $4.16 * *$ & 0.294 \\
\hline & GUA & $\begin{array}{r}-0.2993 \\
(-1.28)\end{array}$ & $\begin{array}{r}0.0033 \\
-0.2\end{array}$ & $\begin{array}{r}-9.3172 \\
(-23.00) * * *\end{array}$ & 23 & 0.82 & 0.0758 \\
\hline & HON & $\begin{array}{r}0.1888 \\
-0.93\end{array}$ & $\begin{array}{r}-0.4145 \\
(-13.42)^{* * *}\end{array}$ & $\begin{array}{r}-16.374 \\
(-31.23)^{* * *}\end{array}$ & 23 & $109.02 * * *$ & 0.916 \\
\hline & MEX & $\begin{array}{r}10.1584 \\
(3.33)^{* * *}\end{array}$ & $\begin{array}{r}2.5984 \\
(9.51)^{* * *}\end{array}$ & $\begin{array}{r}-1.1883 \\
(-0.15)\end{array}$ & 23 & $46.39 * * *$ & 0.8227 \\
\hline & NIC & $\begin{array}{r}0.5754 \\
(1.88)^{* *}\end{array}$ & $\begin{array}{r}-0.0271 \\
(-1.09)\end{array}$ & $\begin{array}{r}-4.7661 \\
(-15.43)^{* * *}\end{array}$ & 23 & 1.92 & 0.1607 \\
\hline & PAN & $\begin{array}{l}-0.0362 \\
(-1.56)^{*}\end{array}$ & $\begin{array}{l}-0.0293 \\
(-1.43)^{*}\end{array}$ & $\begin{array}{r}-8.1282 \\
(-17.33)^{* * *}\end{array}$ & 23 & 1.24 & 0.1107 \\
\hline & PER & $\begin{array}{r}-0.0263 \\
(-0.34)\end{array}$ & $\begin{array}{r}-0.0041 \\
(-2.35)^{* *}\end{array}$ & $\begin{array}{r}-4.0806 \\
(-28.10)^{* * *}\end{array}$ & 23 & $5.73 * *$ & 0.3643 \\
\hline & URU & $\begin{array}{r}-2.7719 \\
(-3.82)^{* * *}\end{array}$ & $\begin{array}{r}0.5713 \\
(9.01)^{* * *}\end{array}$ & $\begin{array}{r}59.2764 \\
(57.75)^{* * *}\end{array}$ & 23 & $43.44 * * *$ & 0.8129 \\
\hline & VEN & $\begin{array}{r}0.5103 \\
(2.06)^{* *}\end{array}$ & $\begin{array}{r}-0.0027 \\
(-0.35)\end{array}$ & $\begin{array}{r}-0.0262 \\
(-0.06)\end{array}$ & 23 & $2.85^{*}$ & 0.222 \\
\hline
\end{tabular}

Table 2: Results obtained by the application of function (4) for the seventeen economies (individually) in study. The bias-corrected $t$-statistics are reported in parentheses. ${ }^{*}$ denotes significance at the 10 percent. ${ }^{* *}$ denotes significance at the 5 percent. ${ }^{* * *}$ denotes significance at the 1 percent. The results have been obtained using Stata 12.0 . 
The above table states that individually only ten Latin American economies show a statistically significant regression to explain the relationship between TFP, international outsourcing, and FDI inflows. In the case of Chile, Colombia, Costa Rica, Ecuador, Guatemala, Nicaragua, and Panama the results cannot be considered valid to explain the relationship between the variables studied. Generally, this type of non-significant results are produced by the sample data, which drew on the best statistical data available for each country, and not necessarily compromise the reliability of the econometric model in use.

Furthermore, ten economies have had results that are able to be considered valid due to its statistical significance. These ten economies are Argentina, Bolivia, Brazil, Dominican Republic, El Salvador, Honduras, Mexico, Peru, Uruguay, and Venezuela. The variety of results proposes a difficult way to identify patterns as well as being an example of the diversity of economic performance among countries of Latin America, a direct consequence of their own physical, territorial, social, ideological and political features.

The existence of individual results statistically insignificant proposed the idea of repeating the general analysis considering only the ten economies that showed significant results. The following table shows the test results for these economies:

Table 3. Results of the model for ten selected economies.

\begin{tabular}{lrrrrrr}
\hline & \multicolumn{1}{l}{ OS } & \multicolumn{1}{c}{ InFDIS } & \multicolumn{1}{c}{ Constant } & Number of Obs. & F-Statistics & \multicolumn{1}{c}{$\mathbf{R}^{2}$} \\
\hline \multirow{2}{*}{ InTFP } & -8.5698 & 1.8554 & -18.6497 & 230 & $5.85^{* * *}$ & 0.049 \\
& $(-0.74)$ & $(3.19)^{* * *}$ & $(-0.88)$ & & & \\
\hline
\end{tabular}

Table 3: Results obtained by the application of function (4) for ten economies (jointly) in study. These economies are Argentina, Bolivia, Brazil, Dominican Republic, El Salvador, Honduras, Mexico, Peru, Uruguay and Venezuela. The bias-corrected $t$-statistics are reported in parentheses. ${ }^{*}$ denotes significance at the 10 percent. ${ }^{* *}$ denotes significance at the 5 percent. *** denotes significance at the 1 percent. The results have been obtained using Stata 12.0.

The positive relationship between the variables of interest in this investigation suggests that an increase in FDI inflows would impact on the productivity growth of the countries analysed at a fairly high rate. This rate is understandable when is noted that Latin American economies are characterized by being highly susceptible to radical changes in their respective performances when they have greater access to productive factors; in this case, capital inflows can affect significantly the growth performance of the countries studied. As expected, the FDI maintains a positive relationship with the TFP growth. Therefore, attracting foreign capital is justified for the countries of the region, both individually and jointly. 


\section{CONCLUSIONS}

As mentioned before, only ten countries have presented significant results according to the F-statistics test of hypothesis for the individual results of the proposed model. These countries are Argentina, Bolivia, Brazil, Dominican Republic, El Salvador, Honduras, México, Perú, Uruguay and Venezuela. It is remarkable that countries like Colombia and Chile - relevant in the economic activity of South America-, or Costa Rica and Panama -emerging economies based on trade liberalization in Central America-, did not figure in the significant results - as shown in table $2-$. The diversity of results between countries could be explained by the complexity and inherent diversity of the region, in economic, politic and social terms.

In the case of the ten countries mentioned above, the F-statistics and their respective hypothesis testing denote there is at least one valid linear relation between the independent variables (Outsourcing and/or the FDI) and the dependent variable (TFP). According to ECLAC (2018), the exporting sector is highly related to the manufacturing sector which is the main recipient of FDI in the region. The competitiveness and productivity of these 10 countries have developed since 1990 with the market opening until 2007 with a decrease in the productivity level given by the currency appreciation and high labor cost in Brazil and Colombia, but a strong productivity growth in Mexico and the rest of South-American countries given by currency depreciation and low labor costs. From 2012 the productivity was reduced on these 10 countries.

Additionally Peru and Uruguay have developed a robust institutional framework and, in the case of Peru, some aggressive reforms during this period. The use of economic policies supported a more open economy, encouraging investment and the creation of a solid institutional framework that guarantees the necessary conditions to receive FDI in the manufacturing sector and increase the TPP regardless of the growth of other sectors.

In the case of Argentina, both independent variables have a valid linear relation with the TFP -as noted by the t-statistics for each independent variable and their respective hypothesis testing, as shown in table 2-. There is actually a positive relationship between all variables that allows us to conclude the TPF of the same country increases if there is an increasing behavior of both Outsourcing and FDI. For the same case, our model explains around 26 percent of the behavior of TFP, which is consistent with our expectations.

In the same way, we conclude there is a similar and valid positive relation between all the variables in another country in the study: Mexico. In the Mexican case, our model explains around 82 percent of the behavior of TFP. It is noteworthy that Mexico and Argentina are the only two countries that present 
such positive relations in their results, due to the different specification of FDI they attract. In the case of Mexico, a natural partner of the Us due to their neighborship, it is notable that the FDI it receives is focused on the relocation of just a part of the production system taking advantage of NAFTA and the cheaper labor supply in the Mexican side of the border, and making lower technology transfer than in the case of Argentina. The South American country received another kind of FDI; due to its geographical location, FDI is more profitable if the whole production system is relocated near the South American consumers, making technology transfer more relevant. In the case of this study, it is notable that both countries present positive relations between TFP, Outsourcing, and FDI spillovers, even when the specifications of these FDI spillovers are different. Recent political changes, internal and external, could be harmful to the Mexican case, in terms of FDI attraction and its implication on productivity and competitiveness. However, the automotive sector has been the engine in both countries in the last 20 years. The incoming FDI has been addressed to the manufacturing sector by the automotive industry increasing the TFP.

The results of the Dominican Republic show that, in their case, both independent variables are useful to explain TFP. In the case of the Outsourcing, it is observed a positive linear relationship with the TFP, statistically significant at the 1 percent level. But, in the case of FDI, a negative linear relation is shown. Noting that the coefficient of the FDI variable is rather small and that it is significant only at the 10 percent level, we strongly recommend expanding the number of annual observations in order to get more specific results.

There is only one country that shows significant value in both independent variables: Uruguay. This country presents both Outsourcing and FDI significant at the 1 percent level. In this case, the FDI spillovers are expected to have a linear and positive valid relation with the TFP, which could be an indication that international economic relations are actually desirable for this country. Due to the negative relation between Outsourcing and TFP, it is suggested that this kind of labor activities should be effectively regulated to assure their importance on the country's development plan.

Both Honduras and Peru present equivalent results. In their cases, only the FDI variable has been significant -at the 1 percent level in both cases-, and the linear relation with the TFP has been negative. According to our model, receiving FDI is actually undesirable for these countries. In both cases, the negative value of the constant $(\beta 0)$ can be interpreted as a negative behavior of the TFP even when the Outsourcing and the FDI are not changing. We assume that our model might be not efficient enough to measure the TFP behavior in the specific conditions of these countries. These conditions might include social behaviors - by example, the relevant violence in the social life of Honduras, 
and its highly recognized immigration to North America-; internal and external political changes - by example, the recent presidential election in Peru-, among others.

In the case of Bolivia, Brazil, Venezuela, and El Salvador, there is only one valid linear relation in the model. For the four cases, the FDI is not a valid variable to explain the behavior of the TFP, but Outsourcing is. The TFP would grow if there is an increasing behavior of the Outsourcing in Bolivia and El Salvador. A different perspective is given for Brazil and Venezuela, where a positive change in the Outsourcing variable would represent a negative variation of their respective TFP.

When the ten countries were analysed jointly, the model has been found as relevant and valid at a 1 percent level of significance. The Outsourcing does not have a valid linear relation with the TFP and it is not able to explain the TFP behavior with the variation of the same variable. In the case of the FDI, there is, as expected, a positive and valid linear relation with the behavior of TFP. At a level of significance of 1 percent, we can say that the FDI has explained the 4.9 percent of the behavior of the TFP of the mentioned ten countries during the period of time from 1990 to 2012. The negative value of the constant $(\beta 0)$ allows us to conclude that the FDI inflows are relevant to the region - jointly- and present potential benefits for enhancing the productivity of some of the Latin American countries. Therefore, in our consideration, the recent political changes in the major partners of the region, the US and the EU, could impact negatively the attraction of FDI by the Latin American countries; inducing, therefore, a negative impact on the productivity of the countries analysed.

In the case of Costa Rica, Chile, Colombia, and Panama, and according to ECLAC (2018) the currency appreciation plays against the exporting sector which is the engine of the manufacturing productivity and, consequently on the TFP, mainly from 2005 to 2012 . A similar feature on these countries is the sector heterogeneity; even when the labor productivity grew during the period in some economic sectors, the decline of labor productivity in the manufacture sector in many years during the analysed period is a common fact on these countries.

The results presented here are part of the literature related to productivity and FDI. As mentioned in the literature before, there are contradictory results in this relation. In the first result, we realize that at a global level there is a significant and positive relation between FDI and productivity. We agree with the bulk of the literature. However, at the country level, the results are ambiguous. In some cases there is a vigorous relation between FDI on productivity, generally in developing countries with a dependency on foreign resources. On the other hand, the relationship between foreign investment and productivity is not clear or even negative. The relevance of this paper regarding the rest of the literature is 
that we include the analysis of the Latin American region. We got a similar result in global terms but ambiguous at a regional level. It may be explained by the influence of foreign firms on the economic structures of these countries. Other countries present no positive relation. This paper is the first in getting some sub-regional results for this issue.

\section{REFERENCES}

Aghion, Philippe \& Howitt, Peter (1992), "A model of Growth through Creative Destruction”, Econometrica, 60 (2), pp. 323-351.

Agosin, Manuel R. \& Mayer, Ricardo (2000), "Foreign direct investment in developing countries”, Unctad Discussion, Paper No. 146, Geneva.

Alfaro, L. \& Rodríguez-Clare, A. (2004), "Multinationals and Linkages: An Empirical Investigation”, Economia, 4, pp. 113-170.

Azeroual, Mohamed (2016), "The Impact of Foreign Direct Investment on the Productivy Growth in the Moroccan Manufacturing Sector: Is Source of FDI Important?", Journal of International and Global Economic Studies, 9 (1), pp. 29-45.

Barro, Robert (1990), "Government Spending in a Simple Model of Endogenous Growth", Journal of Political Economy, 98, pp. 103-125.

(1991), "Economic Growth in a Cross Section of Countries", Quarterly Lournal of Economics, 106 (2), pp. 407-443.

Barro, Robert \& Sala-i-Martin, Xavier (1995), Economic Growth, New York, McGraw-Hill.

Borensztein, Eduardo; de Gregorio, Jose \& Lee, Jong-Wha (1998), "How does foreign direct investment affect economic growth?", Journal of International Economics, 45, pp. 115-35.

Calderón Villarreal, Cuauhtémoc \& Sánchez Juárez, Issac L. (2011), "Apertura, inestabilidad y estancamiento económico en México", en Integración de México en el TLCAN. Sus efectos sobre el crecimiento, la reestructuración productiva y el desarrollo económico, pp. 19-50, México, Miguel Ángel Porrúa.

Campos Pereira, Nádia; Leal Calegario, Cristina Lelis \& Pereira Reis, Ricardo (2013), "Does FDI Cause Higher Levels of Productivity or do Higher Levels of Productivity attract FDI? A Study in Transforming Brazilian Industry", Revista de Ciências da Administraçäo, 15, (35), pp. 82-94.

CEPAL (2014), "La inversión extranjera directa en América Latina y el Caribe 2013", United Nations, Santiago de Chile. 
(2018), "La inversión extranjera directa en América Latina y el Caribe 2018”, United Nations, Santiago de Chile.

Coe, David T. \& Helpman, Elhanan (1995), "International R\&D Spillovers", European Economic Review, 39, pp. 859-887.

Coe, David T.; Helpman, Elhanan \& Hoffmaister, Alexander W. (2008), "International R\&D Spillovers and Institutions", IMF Working Paper, pp. 1-35.

De la Cruz Gallegos, José L.; Boncheva, Antonina I. \& Ruíz-Porras, Antonio (2008), "Competition Between Latin American and China for US Direct Investment", Global Economy Journal, 8 (2).

Díaz González, E. (2011), "Globalización y desigualdad económica en países emergentes", en Integración de México en el TLCAN. Sus efectos sobre el crecimiento, la reestructuración productive y el desarrollo económico, México, Miguel Ángel Porrúa, pp. 291-322.

ECLAC (2018), "Foreign Direct Investment in Latin America and the Caribbean", United Nations, Chile.

Feenstra, Robert C. \& Hanson, Gordon H. (1997), "Productivity Measuremente and the Impact of Trade and Technology on Wages: Estimates from the US, 19721990", NBER Working Paper Series, 6052, pp. 1-49.

Fons-Rosen, Christian; Kalemli-Ozcan, Sebnem; Sorensen, Bent E.; Villegas-Sanchez, Carolina \& Volosovych, Vadym (2013), "Quantifying Productivity Gains from Foreign Investment”, NBER Working Paper Series.

Fujii, Gerardo (2011), "Crecimiento liderado por las exportaciones y la demanda interna. Una visión desde México", en Integración de México en el TLCAN. Sus efectos sobre el crecimiento, la reestructuración productiva y el desarrollo económico, México, Miguel Ángel Porrúa, pp. 79-108.

Fujita, Masahisa; Krugman, Paul \& Venables, Anthony (1999), The Spatial Economy: Cities, Regios and International Trade, Cambridge, MA, MIT Press.

Görg, Holger; Hanley, Aoife \& Strobl, Eric (2005), "Productivity Effects of International Outsourcing: Evidence from Plant Level Data", CEPR Discussion Paper Series, (6361), pp.1-25.

Gray, Kevin R. (2002), "Foreign direct investment and environmental impacts-Is the debate over?", Review of European Community and International Environmental Law 11 (3), pp. 306-313.

Grossman, Gene M. \& Helpman, Elhanan (1991), Innovation and Growth in the Global Economy, Cambridge, MA, MIT Press.

Hermes, Niels \& Lensink, Robert (2000), "Foreign direct investment, financial development and economic growth", Journal of Development Studies, 40 (1), pp. 142-163. 
Javorcik, Beata S. (2004), "Does Foreign Direct Investment Increase the Productivity of Domestic Firms? In Search of Spillovers Through Backward Linkages", American Economic Review, 94 (3), pp. 605-627.

Jordaan, Jacob C. (2008), "State Characteristics and the Locational Choice of Foreign Direct Investment: Evidence from Regional fDI in Mexico 1989-2006", Growth and Change, 39 (3), pp. 389-413.

Juárez Rivera, Carmen G. \& Ángeles Castro, Gerardo (2011), “Determinantes de la inversión extranjera directa en la Republica Mexicana (1994-2007)”, en Integración de México en el TLCAN. Sus efectos sobre el crecimiento, la reestructuración productiva y el desarrollo económico, México, Miguel Ángel Porrúa, pp. 147-166.

Kao, Chihwa.; Chiang, Min-Hsien \& Chen, Bangtian (1999), "International R\&D Spillovers: An Application of Estimation and Inference in Panel Cointegration", Oxford Bulletin of Economics and Statistics.

Keller, Wolfgang (1997), "Are International R\&D Spillovers Trade-Related? Analyzing Spillovers Among Randomly Matched Trade Partners", NBER Working Paper Series, (6065), pp. 1-20.

Kokko, A. (1994), “Technology Market Characteristics, and Spillovers”, Journal of Development Economics, 143 (2), pp. 279-293.

Krugman, Paul R. (1991), "Increasing returns and economic geography", Journal of Political Economy, 99, pp. 183-199.

Krugman, Paul R.; Obstfeld, Maurice \& Melitz, Marc J. (2012), International Economics: Theory \& Policy, Boston, Pearson Addison-Wesley.

Kumar, Nagesh \& Pradhan, Jaya (2002), "Foreign Direct Investment, Externalities and Economic Growth in Developing Countries: Some Empirical Explorations and Implications for wto Negotiations on Investment", New Delhi, Research and Information System for the Non-aligned and other Developing Countries, ris Discussion Paper, No. 27.

Lensink, Robert \& Morrissey, Oliver (2006), "Foreign Direct Investment: Flows, Volatility and the Impact on Growth", Review of International Economics, 14 (3), pp. 478-493.

Lipsey, Robert E. \& Sjöholm, Frederik (2004), "Foreign direct investment, education, and wages in Indonesian manufacturing", Journal of Development Economics, 73 (1), pp. 415-422.

López-Pueyo, Carmen; Barcenilla, Sara; Mancebón, María J. \& Sanaú, Jaime (2008), "La productividad total de los factores en los países desarrollados. Componentes y factores determinantes", Economiaz, 68, pp. 404-429.

López-Bazo, Enrique; Serrano, Guadalupe \& García-Sanchis, José R. (2003), “Complementarity Between Human Capital and Trade in Regional Technological Progress", Regional Quantities Analysis Research Group. 
Luintel, Kul B. \& Khan, Mosahid (2004), “Are International R\&D Spillovers Costly for the US?", The Review of Economic and Statistics, 86, pp. 896-910.

Lukas, Robert (1988), "On the Mechanics of Economic Development", Journal of Monetary Economics, 22, pp. 3-42.

Mankiw, Gregory N.; Romer, David \& Weil, David N. (1992), "A Contribution to the Empirics of Economic Growth", The Quarterly Journal of Economics, 107 (2), pp. 407-437.

Mendoza, J. E. (2011), “Impacto de la inversión extranjera directa en el crecimiento manufacturero en México", Problemas del Desarrollo, Revista Latinoamericana de Economía, 167, (42), pp. 45-70.

Neme Castillo, Omar \& Valderrama, Ana Lilia (2011), "La competitividad tecnológica como determinante de las exportaciones manufactureras mexicanas de largo plazo", en Integración de México en el TLCAN. Sus efectos sobre el crecimiento, la reestructuración productiva y el desarrollo económico, México, Miguel Ángel Porrúa, pp. 211-244.

OECD (2002), Foreign Direct Investment for Development, Paris, OECD.

Ramírez, Miguel D. (2005), "Foreign Capital and Labor Productivity Growth in Chile: An Empirical Analysis”, Revista Latinoamericana de Economía, 36 (140), pp. 43-61.

Romer, Paul M. (1986), "Increasing Returns and Long-Run Growth", Journal of Political Economy, 94 (5), pp. 1002-1037.

(1990), “Endogenous Technological Trade”, Journal of Political Economy, 98 (5), pp. S71-S102.

Sala-i-Martin, Xavier (1997), "I Just Ran Two Million Regressions”, American Economy Review, Papers and Proceedings, 87 (2), pp. 176-183.

Sala-i-Martin Xavier; Doppelhofer Gernot \& Miller Ronald (2004), "Determinants of long-term growth: A Bayesian averaging of classical estimates (BACE) approach", American Economic Review, 94 (4), pp. 813-835.

Stehrer, Robert \& Woerz, Julia (2009), "Industrial Diversity, Trade Patterns, and Productivity Convergence", Review of Development Economics, 13 (2), pp. 356-372.

Takki, Sadayuki (2001), "Productivity Spillovers and Characteristics of Foreign Multinational Plants in Indonesian Manufacturing 1990-1995”, NBER Working Paper Series, (14), pp. 1-30.

Tayebi, Seyed Komail \& Ghanbari, Ali (2008), "Effects of Outsourcing and FDI Spillovers on Productivity of East Asia-Pacific Countries”, Iranian Economic Review, 13 (21), pp. 17-34.

Van Pottelsberghe de la Potterie, Bruno \& Lichtenberg, Frank (2000), "Does Foreign Direct Investment Transfer Technology Across Borders?", Review of Economics and Statistics, pp. 1-26. 
Wang, Yanling (2010), "FDI and productivity growth: the role of inter-industry linkages", The Canadian Journal of Economics / Revue Canadienne d'Economique, 43, (4), pp. 1243-1272.

Witker, Jorge (2010), Introducción al Derecho Económico, México, Mc-Graw Hill. 
